\title{
Electronic and microscopic analysis of offset imprints of barcodes on cardboards
}

\section{ABSTRACT}

The results of analysis of offset imprints of barcodes on cardboards have been offered in this article. The influence of the imprints surface structure on the ink adhesion and the influence of additional varnishing on the barcodes stability to abrasion have been researched. Electronic and microscopic analysis was carried out and their quality parameters were determined - roughness, contrast, optical density.

\author{
Svitlana Havenko \\ Oleksandr Konyukhov \\ Ivanna Konyukhova \\ Ukrainian Academy of Printing, \\ Lviv, Ukraine
}

\author{
Corresponding author: \\ Ivanna Konyukhova \\ e-mail: asdf1966@meta.ua
}

KEY WORDS
barcodes, offset printing, cardboard, ink, structure, electronic microscopy
First recieved: 18.07.2018.

Accepted: 14.02.2019.

\section{Introduction}

It is well- known that the barcodes printed on labels, packaging and other types of products, must meet the standards requirements determining their linear dimensions and permissible deviation. Technologic parameters of barcodes printing are regulated by SSU 3147-96 (State Standard of Ukraine,1995). In the course of printing process a distortion of the barcode dimensions can occur, including the decrease of the stroke width, that is why a correct preparation of original for reproduction within the predefined technology of printing is vitally important. The biggest distortion for linear barcodes is a drop-out of a single width stroke and the change in the geometric dimensions of one of the barcode elements to a single width. Our previous studies have shown that the quality of the printed barcode certainly depends on the technology, ink and substrate properties used in printing as well on the surface structure of the printed item.

The purpose of our research was to study the processes of the interaction between inks and printing substrate which occurs in the offset printing of barcodes and to detect the influence of additional var- nishing of the printed surface on the barcodes stability to abrasion and possibility of their verification.

\section{Methods and Materials}

Offset imprints of packaging barcodes EAN-13 printed on 1-EXCELLENTTOP (GC-2) cardboard made of wood pulp have been used as the object of the research. It has excellent printing characteristics due to a double coating, bleached chemical pulp, mechanic pulp, back side $\left(215 \mathrm{~g} / \mathrm{m}^{2}\right.$, thickness is $340 \mathrm{~mm}$, bulk $\left.1.58 \mathrm{~cm}^{3} / \mathrm{g}\right)$. Pulp board is made of cellulose fibers, back side is light beige. Its front side has a high level of whiteness.

2-Unicolor- GD3 chipboard (or Nikoprint ) grammage is $230 \mathrm{~g} / \mathrm{m}^{2}$, thickness is $0.290 \mathrm{~mm}$, rigidity is $\mathrm{mNm}$ DIN(50) / CD-4.2, rigidity is $\mathrm{mNm} \mathrm{DIN}(50)$ / MD 9.1, rigidity is mNmTaber(150) / CD, rigidity is NmTaber(50) / MD 4.3 The imprints have been made on the offset press Speedmaster XL 106, by EURO 2020, SuperColor set of colours (Italy). The investigation of structure of cardboard surfaces and imprints have been performed by means of MICRO MEASURE 3D station. The investigation of barcode imprints structure at the cross section has been 
made in electronic transmission microscope SELMI ПЭM100- 01 with ultrathin sections and in scanning electronic microscope JEOL T220A (Japan) using Results and Discussion methods (Dembovska, 1978; Tomas, 1983).

The process of printing involves the operations of wetting, capillary absorption, chemical interactions, etc. The investigation of these phenomena have been performed in works of Kozarovìcki I. A., Rebìnder R.E., Deriagin B.V., Velichko O. M., Shybanov V. V., Repeta V. B., Hohlova R. V., Klimova O.D. and other scientists (Hohlova \& Velychko, 2011; Repeta \& Shybanov, 2011; Klimova, 2000). However, despite the extensive researches in this area, there are still important issues which have not been explored fundamentally yet; in particular, the mechanism of interaction between ink (lacquer) and substrate needs further study; the correlation between the amount of ink and optical characteristics of imprints needs to be clarified (Гавенко, Конюхов \& Рибка, 2015; Гавенко \& Конюхов, 2016; Конюхов, 2016). It explains the importance of study of the interaction between ink and printed materials. It is well-known that the quality differences of cardboard surfaces of products may significantly affect the process of ink absorption. The roughness of printed papers and cardboards has a special effect on it (State Standard of the Soviet Union, 1976; Ternycky, 2011; Zydecky, Lazarenko and Lotoshynska, 2001; National standards of Ukraine, 1996).

It is well-known that smoothness (roughness) characterizes the main microstructure of cardboards surfaces and homogeneity is appropriate to the secondary structure of the cardboard, that is its three-dimensional macro homogeneity and influences on the effectiveness of interaction with inks or varnishes. The limits of the roughness values for different types of cardboards are determined by the size of the reproduced image elements. The surface morphology of the examined cardboard GC -2 (a) and GD3 (b) is represented in Figure 1.

The research analysis shows that the average degree of surface roughness of the pulp cardboard GC-2 ranges from -1.52 to $+2.14 \mu \mathrm{m}$, which proves more homogenious distribution of elements of the fibers structure of bleached and chemical thermomechanical pulp, as well the absence of large macroinhomogeneities. However, partly thin deep gaps in the cardboard surface are observed. Two layers of coating are applied on top of the cardboard surface, with roughness parameter $\mathrm{Ra}=11.9 \mu \mathrm{m}$, indicating a highly developed micro-and submicrostructure of the surface. Therefore, double-layered coating provides high development of micro-and submicrostructure of the surface and allows to ensure high quality of printing and varnishing (Ra prints is $15.4 \mu \mathrm{m}$.)

As we can see, cardboard GD3 (2), which is made of recycled paper pulp has an inhomogeneous structure, visible irregularities, which affect the quality of the barcode lines, in particular their uniformity and detail. The study of surfaces morphology shows that the cardboard b) made of pure cellulose possesses a large degree of surface irregularities ranging from -4.56 to $+6.35 \mu \mathrm{m}$; it indicates the disproportional distribution of elements of the surface structure, local clusters of fibers and sparsed areas, which are inherent in cellulose cardboard with the impurities of wood pulp. This is confirmed by roughness parameter $\mathrm{Ra}=13.4 \mu \mathrm{m}$, of the barcode imprints on it $\mathrm{RA}=20.5 \mu \mathrm{m}$.

Research shows that the imprints on the GC -2 cardboard have a greater smoothness than those printed on GD3 cardboard. It occurs because the ink penetrates into large pores of GD3 cardboard due to the lack of coated layer and does not cover properly the irregularities of its surface. Electronic and microscopic investigation of cross sections of a double coated cardboard GC - 2 indicate the presence of pores, filled with particles of kaolin, or other filler having different shape (correct hexagonal shape) and size, and binding particles of coated layer - probably latex. The surface of the particles is fuzzy, blurred, as if covered with polymer film. The structure of the cardboard consists of closely interwoven microfibrils, fibers of bleached, chemical and thermomechanical pulp. Cavities of microfibrous space are irregularly filled with filler (Figure 2a), large aggregates of its particles are observed, they fill pores, leaving a small slit from 0.2 to $1 \mu \mathrm{m}$ and reducing its porosity. Electronic and microscopic investigation of the GD3cardboard structure showed that on the surface of the fibers there are clearly visible oval shaped pores having size up to $6 \mu \mathrm{m}$; as well the micro-fibrils twisted around the pores can be observed; besides, there are visible macro and micropores passing through, which indicate the inhomogeneity of cardboard structure (Figure 2b).

Thus, by means of the cross sections method the depth of ink penetration in the structure of the GC-2 and GD3 cardboards has been investigated and it has been proved that the lower absorption of ink by base contributes to its better adhesion on the surface, and ensures the greater homogeneity of ink distribution on the imprint (Figure 2).

The quality of the barcode also depends on the optical density of the printed image, the magnitude of their contrast, the accuracy of line width reproduction, which in turn depends on the choice of printing method and the characteristics of the materials to which they are applied.

The results of experimental studies (Figure 3), in particular the profile curve lines barcode EAN-13 on the Excellenttop cardboard (GC-2), show that the optical density is 1.26 , the contrast value is 0.15 with a line width of 0.24 $\mu \mathrm{m} \mu \mathrm{m}, \mathrm{Rmax} 0,27 \mu \mathrm{m}$ and $\mathrm{Rmin}$ is $0.23 \mu \mathrm{m}$. 


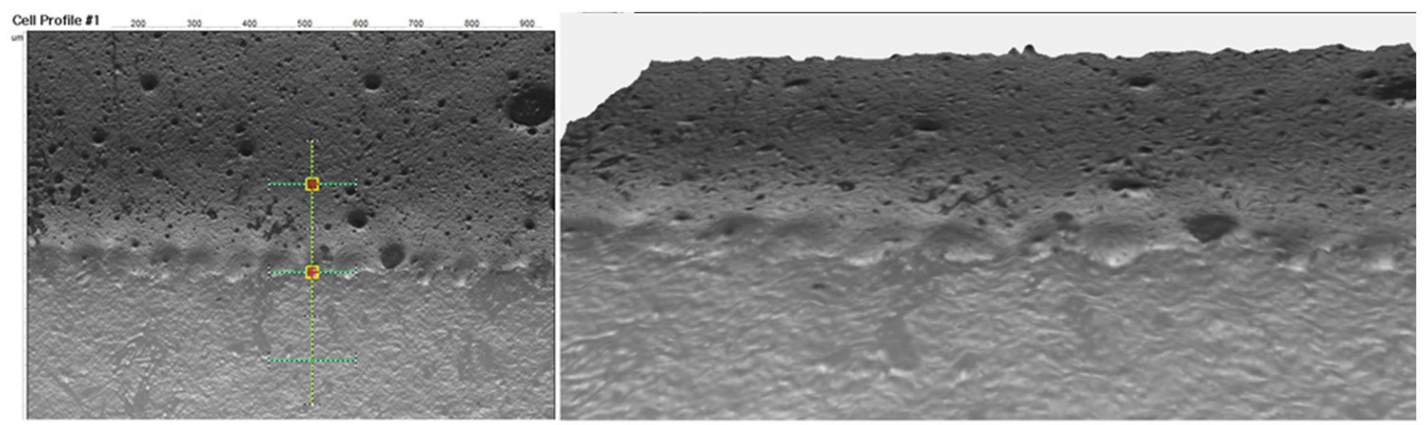

1a)
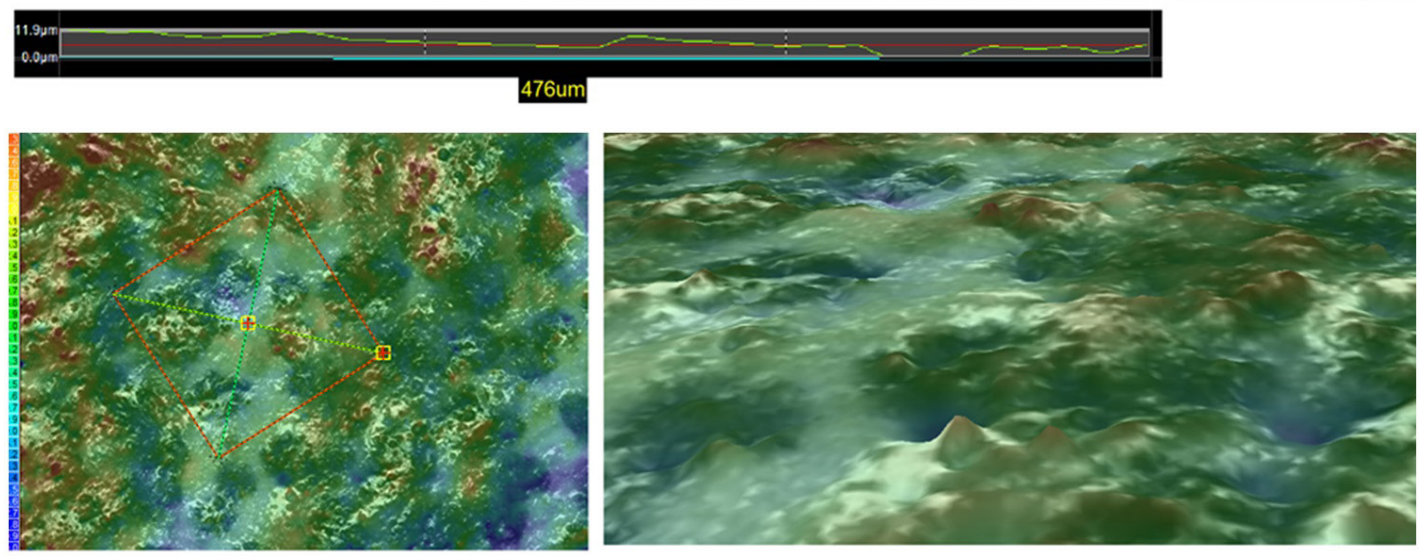

2a)
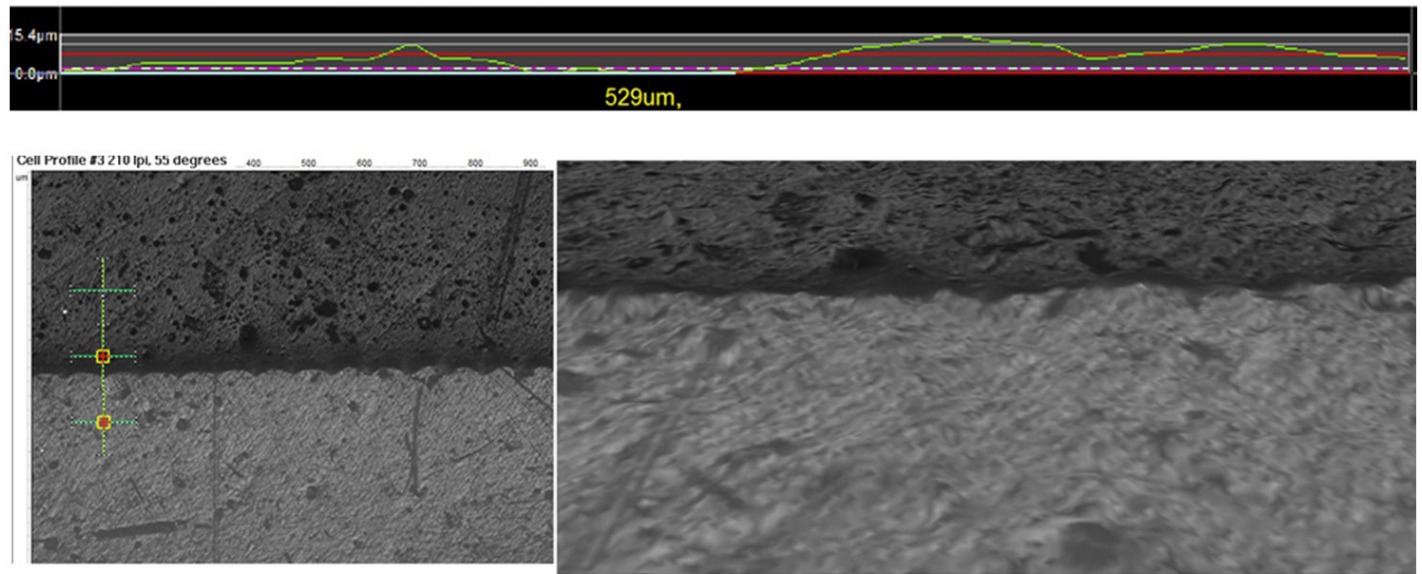

1b)
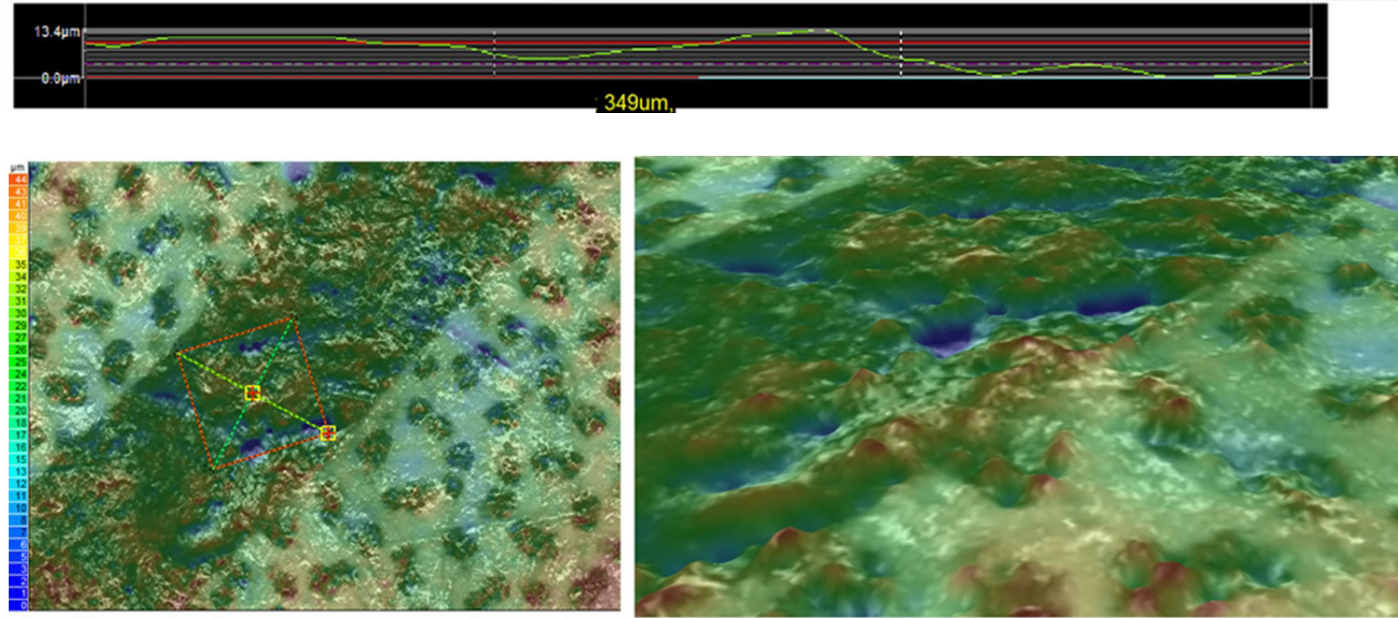

2b)

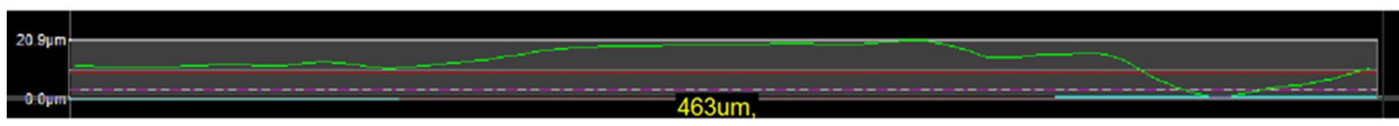

» Figure 1: Three-dimensional image of the cardboards surface (1a and 2a) and barcodes imprints (1b, 2 b) on the cardboards and their profile 
As you know, the imprints on cardboard packing are often covered with lacquer to improve mechanical stability. Figure 4 shows the surface microstructure of the barcode covered by additional varnish and repro- duced on the GC-2 cardboard. A solid layer of lacquer is placed on a smooth surface of barcode reproduced on the cardboard, but the narrow capillaries of cellulose fibers are visible through the lacquer film.
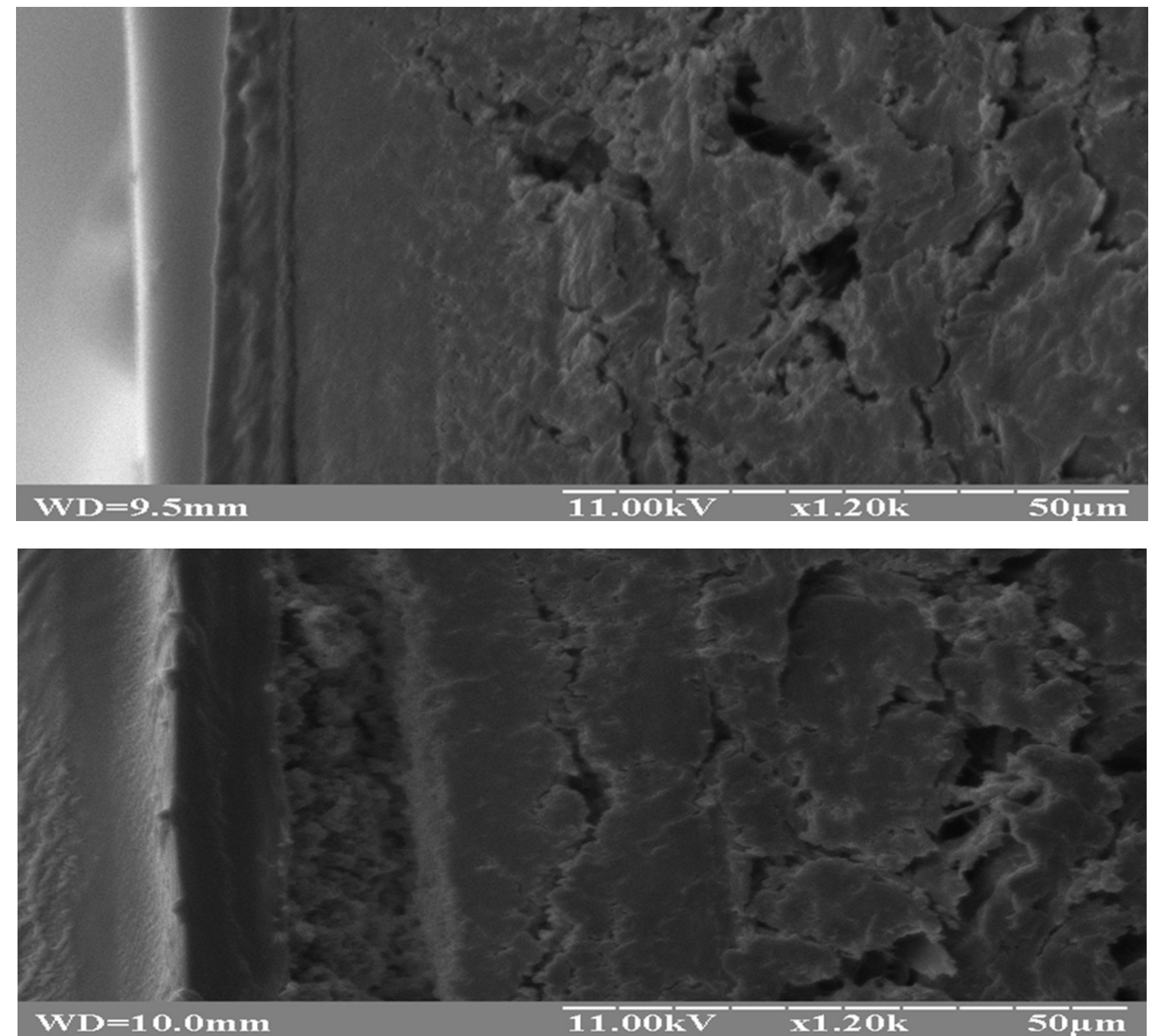

» Figure 2: Electro-microscopic pictures of ultra thin cross sections of the investigated imprints
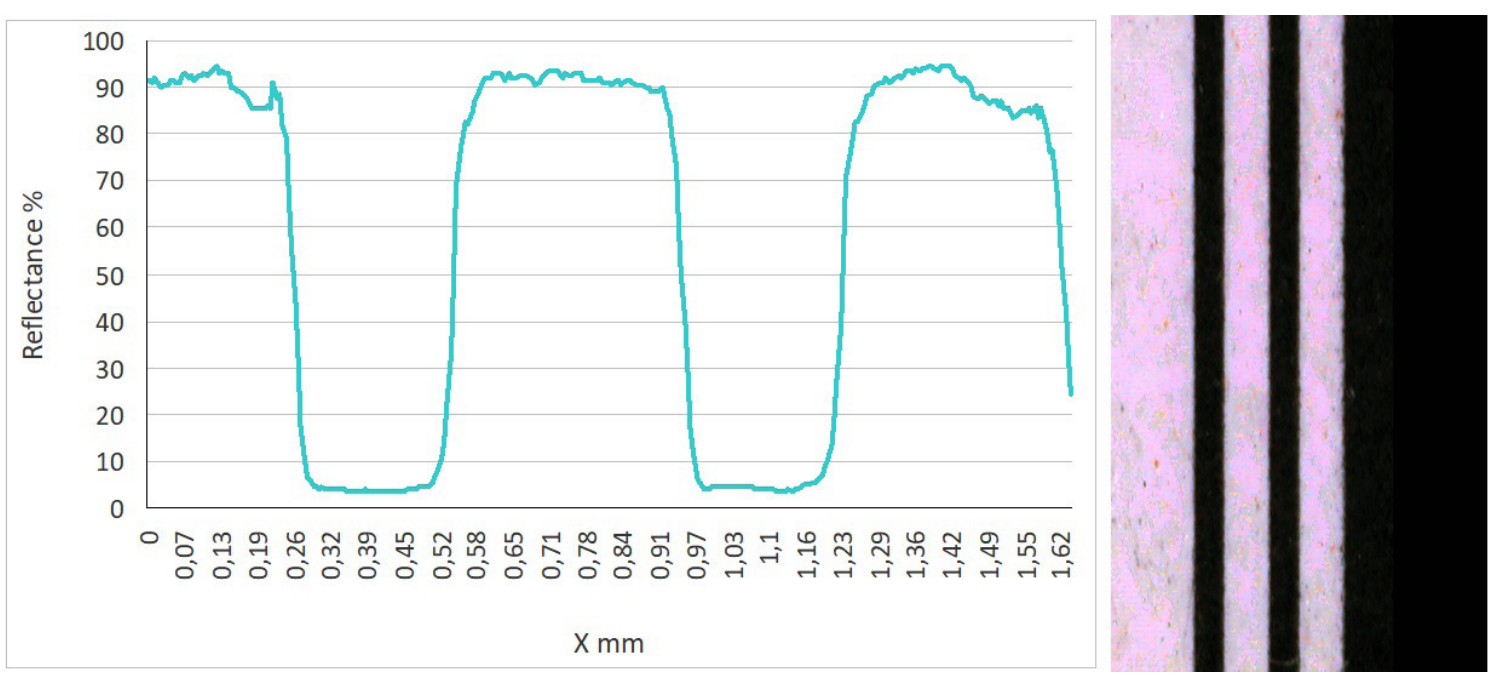

» Figure 3: Profile curve lines barcode EAN-13 (a) and its microphotography (b) (sample number 3) 


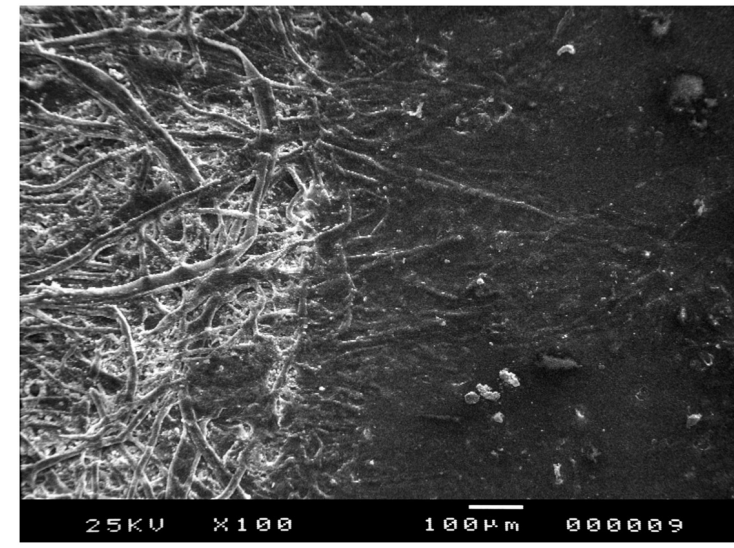

» Figure 4: Microphotography of the boundary between the barcode reproduction and lacquered surface.

The analysis of microphotography of imprints showed that the thickness of the layer of varnish on the cardboard after its solidification remains unchanged, what proves the shallow penetration of varnish into the cardboard structure

A significant influence on the depth of penetration both ink and varnish has the value of its surface tension. UV lacquer with a lower surface tension deeply penetrates into the structure of the cardboard, and some time after applying it to the substrate it is almost invisible, as it is demonstrated on the photos of the cross sections of the investigated samples (Figure 5)
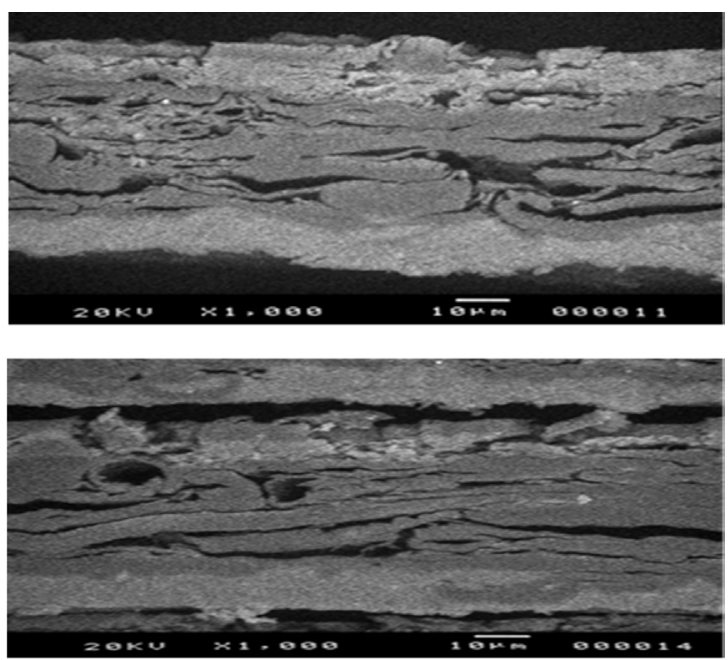

» Figure 5: Microphotographs of ultra thin cross sections of the investigated samples of the cardboards (printed and coated with lacquer layer)

Thus, on the basis of electronic and microscopic researches of the surface morphology of non-printed and printed cardboard, the correlation between parameters of substrate roughness and the mechanism of the interaction of inks (varnishes) has been revealed. It is proved that inks and UV-varnishes with low surface tension penetrate deeper into the structure of the cardboard.

\section{Conclusion}

The results of electronic and microscopic researches proved that the printed surface of the barcode imprint is more homogeneous than the non-printed area; that is indicated by a decrease of the roughness parameter Ra and smoothing of irregularities of investigated substrates; in the final version it will provide the accuracy of the offset reproduction of geometrical parameters of the barcodes and quality of their verification while reading.

The importance of the barcode is its contrast, in particular the ratio of Rmax and Rmin spacing and stroke spaced apart, as well as the optical density in the stabilization zone, since it is known that these relationships affect the qualitative verification of barcodes.

\section{References}

Dembovska, U. (1978) Electron microscopy in printing. Moscow, Book publishing house.

Гавенко С. Ф. \& Конюхов О. Д., \& Рибка Р. В. (2015) Research quality printed barcodes and their abrasion resistance [Дослідження якості надрукованих штрих-кодів та їх стійкості до стирання]. Book Qualilogy-Collection Of Scientific Papers [Квалілогія книги- Збірник Наукових Праць]. 1(27), 19-25. Available from: https://www.google. $\mathrm{com} /$ url? sa $=$ t\&rct=j\& $q=\&$ esrc $=s \&$ source $=$ web \& $c-$ $\mathrm{d}=2 \&$ ved=2ahUKEwjf9bWWj7HiAhUFXRoKHVVrDywQFjABegQIARAC\&url=http\%3A\%2F\%2Fnbuv.gov. ua\%2Fj-pdf\%2FKk_2015_1_5.pdf\&usg=AOvVaw1cAOyPqjyJ7pD4mgWaPli7 [Accessed: Mart 12th 2019].

Гавенко С. Ф. \& Конюхов О. Д. (2016) The experimental studies of conformity of the dimensions of elements of a barcode and structure of barcodes EAN-13 printed on cardboard packaging [Дослідження відповідності розмірів елементів штрих-кодового знаку та структури коду EAN-13 на картонних пакованнях]. Journal of Technology and technique of typography [Технологія і техніка друкарства]. 4(54), 29-38. Available from: doi: 10.20535/20777264.4(54).2016.99447 [Accessed: Mart 12th 2019].

Hohlova, R. \& Velychko, O. (2011) Varnish in the printing and postprinting. Kyiv, Publishing and Printing Center of Kiev University.

Klimova, E. (2000) Photopolymerizing compositions for printing and finishing processes. Moscow, Moscow State University of Printing.

Конюхов О. Д. (2016) Defining the parameters of quality printed barcodes [Визначення параметрів якості надрукованих штрихкодів]. Book Qualilogy- Collection Of Scientific Papers [Квалілогія книги- Збірник Наукових Праць]. 1(29), 64-70. Available from: irbis-nbuv.gov.ua/cgi-bin/irbis_nbuv/cgiirbis_64. exe?C21COM=2\&I21DBN=UJRN\&P21DBN=UJRN\&IM- 
AGE_FILE_DOWNLOAD=1\&Image_file_name=PDF/

Kk_2016_1_10.pdf [Accessed: Mart 14th 2019].

National standards of Ukraine. (1996) 2907-

94:1996. Paper and cardboard. Determination

of stiffness during bending. The method of res-

onance. Kyiv, National standards of Ukraine.

Repeta, V. \& Shybanov, V. (2011) Materials and

technologies of varnishing printing prod-

ucts. Lviv, Ukrainian Academy of Printing.

State Standard of the Soviet Union (GOST).

(1976) 20811-75:1976. Materials for paint and

varnish. Methods for testing abrasion coat-

ings [Материалы лакокрасочные. Методы

испытания покрытий на истирание]. Moscow,

State Standard of the Soviet Union.

State Standard of Ukraine. (1995) 3147-96:1995. Codes

and encoding information. Bar coding. Mark-

ing of objects of identification. The format and

location of the EAN barcode labels on packaging

and packaging of commodity products. General

requirements. Kyiv, State Standard of Ukraine.

Ternycky, S. (2011) Cardboard- its structure, variety,

characteristics and scope of expedient appli-

cation for manufacturing of packages [Картон

- Його Будова, Різновид, Характеристики

І Сфера Доцільногозастосування Для

Виготовлення Пакувань]. Journal of Scientific

Bulletin of NLTU of Ukraine [Науковий вісник

НЛтУ України]. 21(6), 85-90. Available from:

http://old.nltu.edu.ua/nv/Archive/2011/21_6/85_

Ter.pdf [Accessed: Mart 14th 2019].

Tomas, G. (1983) Translucent electron microscopy of

materials. Moscow, Science publishing house.

Zydecky, V. Lazarenko, O. \& Lotoshynska, N. (2001)

Polygraphic materials. Lviv, Poster Polygraph Company.

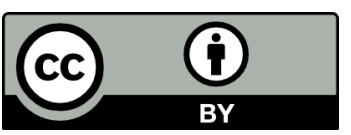

(C) 2019 Authors. Published by the University of Novi Sad, Faculty of Technical Sciences, Department of Graphic Engineering and Design. This article is an open access article distributed under the terms and conditions of the Creative Commons Attribution license 3.0 Serbia (http://creativecommons.org/licenses/by/3.0/rs/). 